\title{
LONG-TERM VIABILITY OF SMART HOME SYSTEMS
}

\author{
Business Modelling and Conceptual Requirements on \\ Technology
}

Greger Sandström, Stig Gustavsson, Stefan Lundberg, Ulf Keijer, Stefan Junestrand

Royal Institute of Technology, The Architectural School, Information Technology, Stockholm, Sweden

Abstract: In Stockholm during the years 1999-2002 some residential housing units provided with advanced IT-based functions were developed, also called smart homes systems. The purpose was to offer the residents an augmented living environment mainly regarding security and comfort. Only the IT company that originally developed the basic system fully knows it in depth, a fact which has shown to become very unfavourable for the residents. The running cost, also for minor changes of the functionality of the system, has turned out to be high and prohibiting. Also the contracted regular maintenance requires access to unique competence, which also has become costly. Recently the company has indicated a replacement of the smart homes system with a simpler one based on the Internet. Business models for viable home systems should include the occupancy phase, which to date have been neglected. A crucial issue is who will and can assume long-term responsibility for surveillance, maintenance, and added functionalities over time. This paper will discuss some principal questions and prerequisites regarding business viability in relationship to smart home systems, and its significance for business modelling.

Key words: Smart homes, sustainability, design, systems.

\section{INTRODUCTION}

In the past five years a number of smart home housing projects were developed in Sweden. During the subsequent post occupancy running phase 
questions have been raised regarding maintenance, repair and upgrading of the installed smart home functionalities. Maintenance and running costs are in general not important issues in the construction phase of a housing project, let alone energy conservation. Also in these projects the long-term issues were by and large neglected during the planning phase, including the smart home systems. This paper will discuss some issues regarding maintenance of smart home systems and related technological requirements, based upon the experiences from some smart homes developments, now in their occupancy phase.

Below a brief description is given of the smart homes concept and of principal roles and actors forming necessary constituents of the construction process. A case study will be outlined. Further, some typical information entities to be handled by an integrated smart home system are illustrated and it is discussed how this information could be preserved over time. To conclude the presentation possible business actors for the development and maintenance of smart home system are introduced.

\subsection{Smart Homes}

In traditional homes a considerable number of principally autonomous systems and networks support daily life, e.g. telephony, access control and security, household appliances, television, PC (data) networks, audio and video information and entertainment systems, lighting, electricity, ventilation, heating, air-conditioning, water supply and more. Generally, these systems are not connected or functionally integrated into each other. However, the connection of single household appliances and systems to networks and more complex systems has begun. Its technological and functional roots are found in intelligent buildings that arose and became important for the building industry in the 1970s. Intelligent buildings initially focused on commercial premises, i.e. offices and industrial buildings, providing technology for sensing and control, primarily out of a building management perspective. When the discussion turned from operation (of buildings) to living in buildings (homes), the term smart homes became generally used.

Smart homes are homes provided with some integrated technological system offering remote or central controlled functionalities and services ${ }^{3}$. In

${ }^{3}$ Example of services that can be created by the integration of the different systems are for example if a water leakage is detected at the laundry machine in the kitchen when nobody is at home, the water supply to the home is automatically turned off and telephone calls are 
a smart home the inhabitants' desires and needs concerning all or a (substantial) part of these aforementioned equipment and functionalities are in focus. In principle, the technological infrastructure is based on the integration of the systems for home automation, security, multimedia and telecommunication. The systems are connected to each other and to the outer world through a residential gateway, see figure 1. Recently, it has become obvious that wireless connections may be just as viable as an alternative to wired solutions. The residential gateway could in this case be located outside the home.

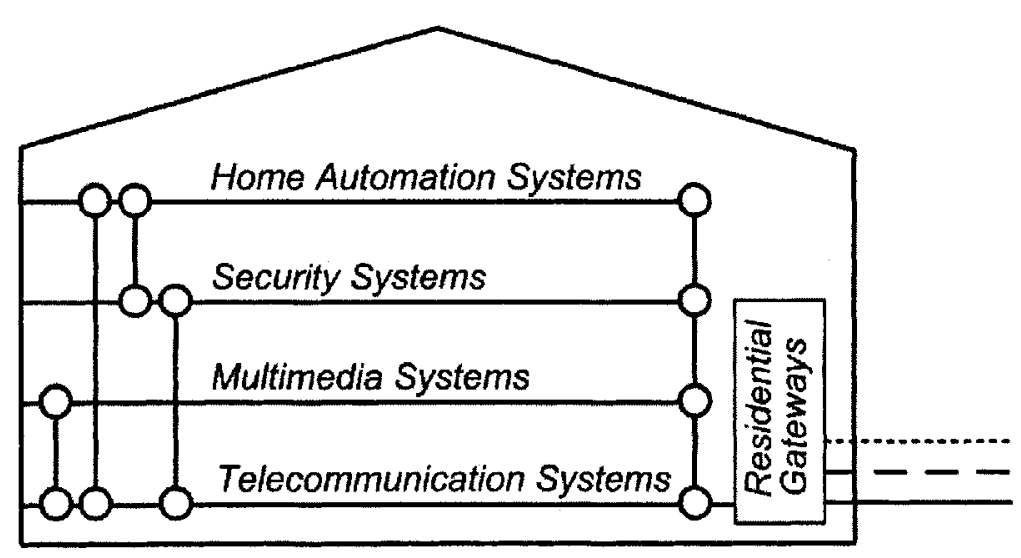

Figure 1. A schematic model of a technical structure of a smart home (Junestrand, 2004).

\subsection{Models for organisation and business}

An organisational model represents a company's total operation or a specified part of it. It usually takes the form of a graphic depiction of the structure and activities, accompanied by an explanatory legend or full text. The operation could likewise be project undertakings of various kinds, e.g. construction projects. There is a multitude of modelling tools available in order to describe organisations, their tasks and their business operation (see e.g. Barnley et al. 1986; Tarandi 1998 citing Mayer 1994). In this paper a task model related to the establishment of smart homes will be discussed and

generated to the pre-programmed telephone numbers, an SMS or an instant message is sent. Or when all the family has gone to bed a push-button upstairs will turn off the lights, bring down the blinds, lower the temperature $5^{\circ} \mathrm{C}$ and turn on the alarm. At $7 \mathrm{a} . \mathrm{m}$. the next day the blinds automatically rise, the lights in the hallway and kitchen are turned on, the alarm is turned off and the temperature has been brought up to the normal $21^{\circ} \mathrm{C}$. 
how this model would support also the occupancy phase. Maintenance over time is a key factor for a viable development and marketing of smart homes on a broader scale.

As all business ends up with the customer, the first question asked is:

- "How is a viable organisational and business model designed in order to create prevailing added value for the residents?"

Further

- "What are the tasks and what are the actors' roles when included in the model? What are the requirements on the actors so to fulfil these roles?" and

- "Are there essential features of a viable home network system to facilitate the tasks?"

This paper should be considered as an embryonic attempt to understand a fundamental problem of how to secure a sound development of the smart home business for the next few years lying ahead.

\section{THE STUDY OBJECT}

In the heart of Stockholm, a smart home residential housing unit, called Vallgossen was constructed. First occupancies took place in September 2001. Vallgossen comprises 126 flats in total. Their sizes vary from 44 to 144 square meters.

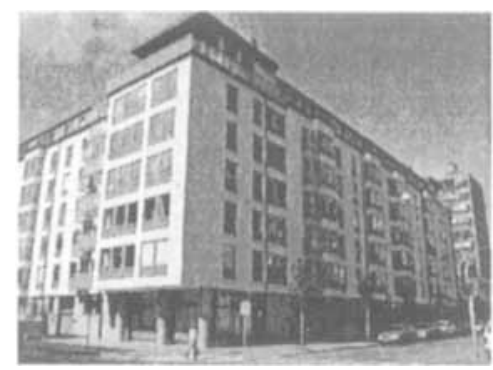

Figure 2. The Vallgossen project

In Vallgossen all 126 flats are equipped with a basic smart home system called "type 1 ", while 21 flats have an additional, more advanced system, "type 2 ". Two additional flats were test units for trying out assisted living, and equipped with some complex equipment for rehabilitation purposes (Sandström and Keijer, 2003). 
The smart home system in each flat is accessed via a laptop computer. An important objective when designing the smart home system was to make its physical appearance as invisible as possible. Another objective was to make it user-friendly. It should not be necessary to control the system in order to live well in the flats. The smart home system provides the residents with information about security, energy consumption and available facilities, e.g. for booking the common laundry machines. It includes a family calendar and ordinary e-mail. It is possible to leave e-notes to other members of the family and to create a common reminder list.

The basic idea was that the smart home system should play a central role in the residents' everyday life. The residents would be able to gather important everyday family information in one place, e.g. to communicate with each other (e-notes), to communicate with their friends (e-mail and address book) and to co-ordinate their activities (calendar). Further, it would help them to feel safer at home (alarms) and to have control over their energy use. The availability of appropriate technology at the time defined the functionality of the installed systems. Noteworthy, when this building system was planned there was limited knowledge of the consumers' opinions and their perceived valuation of the available smart functions.

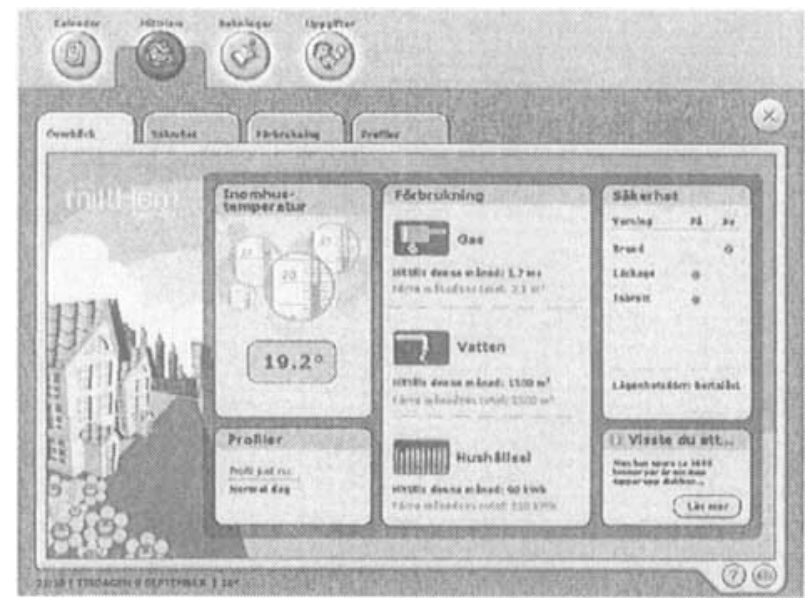

Figure 3. Example screen shot of the home network

The smart home system has been evaluated with regard to the residents' opinions (Sandström et al., 2003). It was found that the IT functions were not a conclusive reason for acquiring these flats; the households considered them rather as a bonus. Still the IT functions represent a habitation value. Functions increasing safety and security (e.g. alarms) and saving time (e.g. booking of common facilities) were the most appreciated functions. The 
possibility of energy conservation and of access to separate non-integrated functions was less appreciated. In a recent survey the residents in Vallgossen were asked "Specify to what degree you would miss the following functions if they are not available in your next home?". The results regarding some of the functions are found in table 1.

Table 1. Residents' opinions regarding smart homes functionalities

\begin{tabular}{|c|c|c|c|c|c|}
\hline & $\begin{array}{c}\text { very small } \\
\text { degree / } \\
\text { not at all }\end{array}$ & $\begin{array}{l}\text { small } \\
\text { degree }\end{array}$ & $\begin{array}{c}\text { high } \\
\text { degree }\end{array}$ & $\begin{array}{c}\text { very } \\
\text { high } \\
\text { degree }\end{array}$ & $\begin{array}{c}\text { no } \\
\text { opinion }\end{array}$ \\
\hline Fire alarm & - & $1 \%$ & $5 \%$ & $94 \%$ & - \\
\hline Burglar alarm & - & $2 \%$ & $14 \%$ & $84 \%$ & - \\
\hline The "away-lock" & $6 \%$ & $1 \%$ & $22 \%$ & $71 \%$ & - \\
\hline Electronic keys & $1 \%$ & $9 \%$ & $30 \%$ & $60 \%$ & - \\
\hline $\begin{array}{l}\text { Bookings of common } \\
\text { facilities }\end{array}$ & $9 \%$ & $16 \%$ & $28 \%$ & $46 \%$ & $1 \%$ \\
\hline $\begin{array}{l}\text { Individual energy } \\
\text { measurement with } \\
\text { graphical presentation } \\
\text { of consumption }\end{array}$ & $24 \%$ & $45 \%$ & $18 \%$ & $10 \%$ & $3 \%$ \\
\hline
\end{tabular}

\section{THE SWEDISH CONSTRUCTION MARKET}

Many parties are involved in a typical housing construction undertaking. Many different roles are identified. In this article the client is defined as the developer of the undertaking. In particular this means that the clientdeveloper takes the ultimate financial risk. The client is the body (person or company) that defines the building product, procures all site work and deliveries, monitors the construction work and is responsible for its proper completion. The client obtains the building permit and takes the prime responsibility for fulfilling any rule with respect to the undertaking. Especially, in this case, the client-developer purchased the entire smart home system from an IT system provider. The latter was backed by leading Swedish appliances and telecom industries.

Housing construction is carried out both by public and private companies. To a large extent the private construction companies transfer the completed building to some final owner or manager.

In Sweden there is a special type of residential housing, particularly in focus for this paper, where someone pays down a lump sum and acquires membership in a housing association, which has acquired the building. With 
the membership is associated a legal right to occupy a specific predefined flat.

The responsibility for the proper function of the building rests with the developer as a two-years warranty. This warranty is based on a long experience within the building industry. However, for complex structures, like smart home systems, such a limited warranty has shown to be insufficient. For the Vallgossen project the warranty period of the smart homes functions was extended another three years, see figure 3 . As will be obvious below, the extension did not remedy the topical problem significantly. It postponed the pop-up of occurring problems a few years, nothing else.

It is clear that the end-users, the residents, have very little influence during the planning and construction process. Of course, this may cause problems already for traditional housing occupancy. These problems may increase considerably when a smart homes system is added.

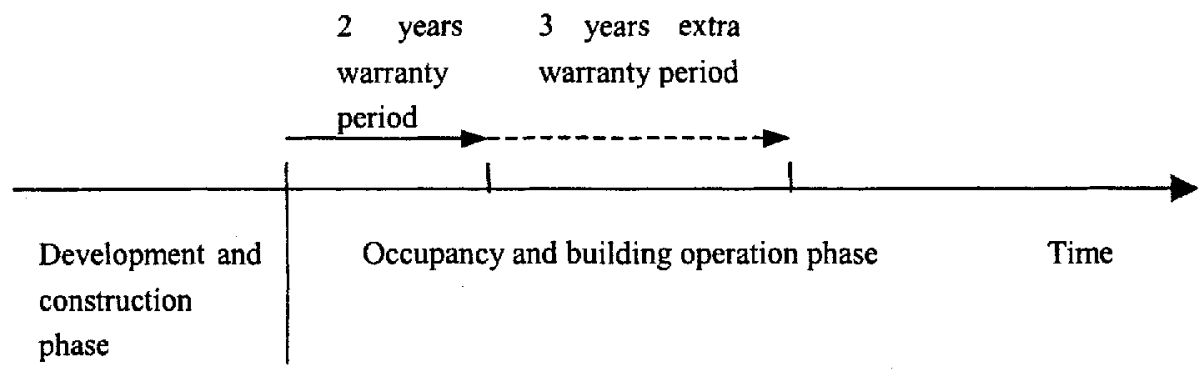

Figure 4. Extended warranty period, exclusively for the smart home

Already two years after the occupancy, the IT system developer closed down its activity and outsourced maintenance and support of the smart home network system to another company. Some employees, with unique competence, were transferred to this new company.

\section{ORGANISATIONAL MODEL FOR THE VALLGOSSEN DEVELOPMENT}

The developer initiated the idea of introducing smart homes in Vallgossen. The market for smart homes was growing and the client had to take some new initiatives. However, the available IT systems on the market were based on ideas and prototypes. The developer had not only to sign contracts with entrepreneurs (which he is used to) but also to define demands on the IT system, its design and functionality. 
Table 2. Roles and dependencies in the construction process including smart home functions

\begin{tabular}{|c|c|c|c|c|}
\hline \multirow[t]{2}{*}{ Role } & \multirow[t]{2}{*}{ Code } & \multirow[t]{2}{*}{ Task } & \multicolumn{2}{|c|}{ Dependencies } \\
\hline & & & $\begin{array}{c}\begin{array}{c}\text { Dependen } \\
\text { t on }\end{array} \\
\end{array}$ & \begin{tabular}{|c|}
$\begin{array}{c}\text { Controls/Co- } \\
\text { ordinates }\end{array}$ \\
\end{tabular} \\
\hline Client-developer & $\mathrm{C}$ & $\begin{array}{l}\text { Organises the whole undertaking. } \\
\text { Takes the financial risk until the } \\
\text { homes are fully transferred the } \\
\text { owners. }\end{array}$ & EU & $\begin{array}{l}\text { All, except } \\
\text { EU }\end{array}$ \\
\hline $\begin{array}{l}\text { Project } \\
\text { Management }\end{array}$ & PM & $\begin{array}{l}\text { Co-ordinate tasks between the client- } \\
\text { developer and consultants, } \\
\text { subcontractors and providers. }\end{array}$ & $\mathrm{C}$ & $\begin{array}{l}\text { All, except } \\
\text { C and EU }\end{array}$ \\
\hline Architect & A & $\begin{array}{l}\text { Principal consultant (in Sweden, } \\
\text { however, with less superiority than } \\
\text { in most other countries) }\end{array}$ & PM & $\begin{array}{l}\mathrm{CS}, \mathrm{CM} \text {, } \\
\mathrm{CE}, \mathrm{CSH}\end{array}$ \\
\hline $\begin{array}{l}\text { Consultant } \\
\text { (structural) }\end{array}$ & $\mathrm{CS}$ & $\begin{array}{l}\text { Develops blue prints for the structure } \\
\text { in the building. }\end{array}$ & PM, A & \\
\hline $\begin{array}{l}\text { Consultant } \\
\text { (mechanical) }\end{array}$ & $\mathrm{CM}$ & $\begin{array}{l}\text { Develops blue prints for HVAC } \\
\text { system in the building. }\end{array}$ & PM, A & SM \\
\hline $\begin{array}{l}\text { Consultant } \\
\text { (electrical) }\end{array}$ & $\mathrm{CE}$ & $\begin{array}{l}\text { Develops blue prints for the } \\
\text { electrical system in the building. }\end{array}$ & PM, A & SE \\
\hline $\begin{array}{l}\text { Consultant (smart } \\
\text { homes) }\end{array}$ & $\mathrm{CSH}$ & $\begin{array}{l}\text { Co-ordinates IT installations } \\
\text { between consultants, contractor, } \\
\text { subcontractors and providers. }\end{array}$ & PM, A & \begin{tabular}{|l|} 
SSH, SM, \\
SE, PAP, \\
PC, PAC \\
\end{tabular} \\
\hline $\begin{array}{l}\text { Subcontractor } \\
\text { (mechanical) }\end{array}$ & SM & $\begin{array}{l}\text { Install HVAC on the construction } \\
\text { site. }\end{array}$ & $\begin{array}{l}\text { PM, CM, } \\
\text { CSH }\end{array}$ & \\
\hline $\begin{array}{l}\text { Subcontractor } \\
\text { (electrical) }\end{array}$ & SE & \begin{tabular}{|l}
$\begin{array}{l}\text { Install electrical wires on the } \\
\text { construction site. }\end{array}$ \\
\end{tabular} & \begin{tabular}{|l} 
PM, CE, \\
CSH \\
\end{tabular} & \\
\hline $\begin{array}{l}\text { Subcontractor } \\
\text { (smart homes } \\
\text { system) }\end{array}$ & SSH & $\begin{array}{l}\text { Install the IT system on the } \\
\text { construction site. }\end{array}$ & PM, CSH & \\
\hline $\begin{array}{l}\text { Provider } \\
\text { (appliances) }\end{array}$ & PAP & $\begin{array}{l}\text { Delivers appliances to the } \\
\text { construction site. }\end{array}$ & SSH & \\
\hline $\begin{array}{l}\text { Provider } \\
\text { (windows, doors, } \\
\text { etc.) }\end{array}$ & PC & $\begin{array}{l}\text { Delivers windows, doors, etc to the } \\
\text { construction site. }\end{array}$ & A, SSH & \\
\hline $\begin{array}{l}\text { Provider (access } \\
\text { systems) }\end{array}$ & PAC & $\begin{array}{l}\text { Delivers the access system to the } \\
\text { construction site. }\end{array}$ & A, SSH & \\
\hline $\begin{array}{l}\text { The end user (the } \\
\text { resident) }\end{array}$ & EU & The residents occupying the flats. & & \\
\hline
\end{tabular}

The different roles necessary for the organisation of the planning and realisation of the homes are the client-developer, the architect, a number of professionals-consultants and subcontractors, see Table 1 . The table could be extended, however, it is considered to be sufficient for the purpose of this article. Note the two roles, the smart home consultant (CSH) and the smart home system provider ( $\mathrm{SSH}$ ), both representing entirely new tasks to be fulfilled in the construction process.

The smart home system subcontractor's commitment (see table 1) is primarily characterised by the long-term agreement with the client- 
developer, in Vallgossen five years, figure 2. The smart home system, which is a part of the service agreement, contains both software and hardware. Due to fast development of ICT, uncertainty concerning the future needs of maintenance and costs of the smart home system will be intrinsic. Contractual conditions putting demands on both the installed home system and on the agreement as such are difficult to formulate unambiguously. Especially, the end users' best interest is difficult to maintain over time. So called agent theory may offer additional perspectives useful for the treatment of uncertainties between the principal and the service provider (the agent), including contractual provisions and terms of reward (see Jensen \& Meckling, 1976; Eisenhardt, 1989).

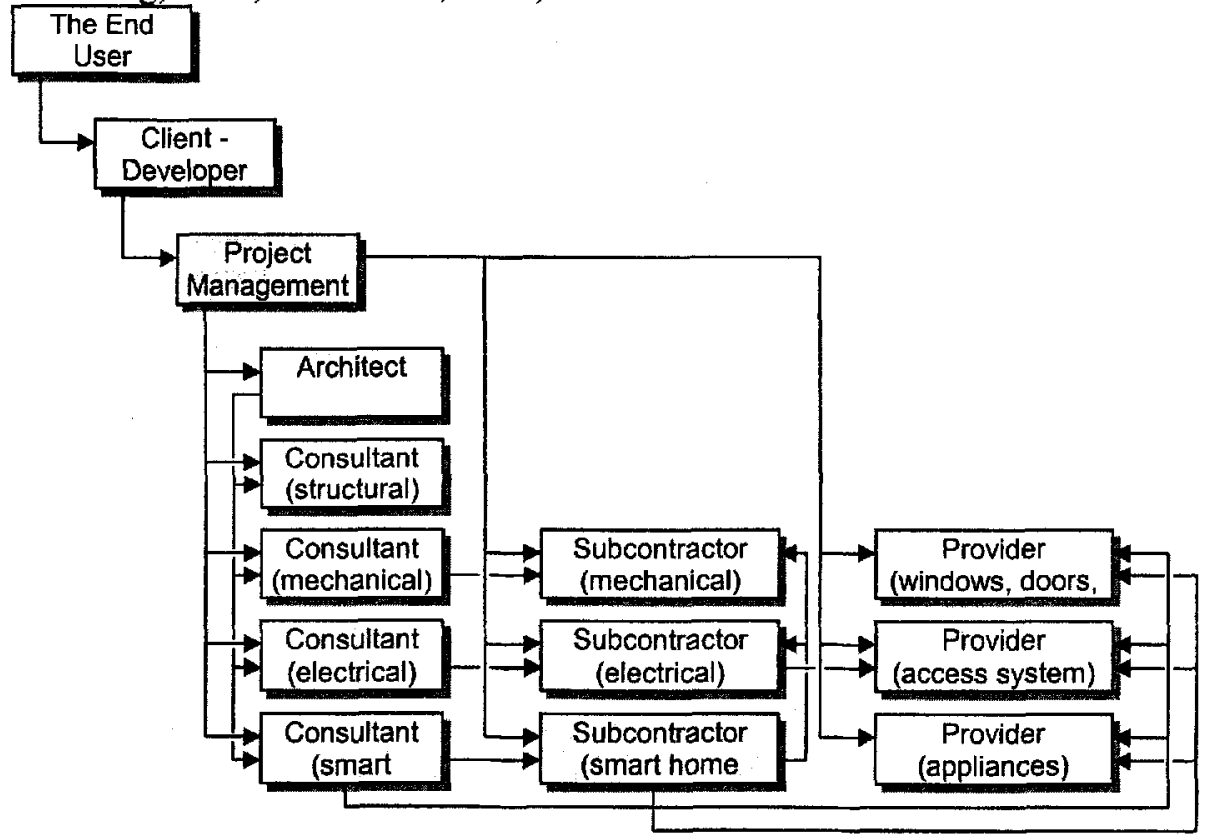

Figure 5. Co-ordination and dependencies in the building process including smart homes (IDEF0 notation).

Table 2 is largely mapped into a semantic schema depicted in figure 5. It is obvious that the introduction of the smart home system has increased the interdependencies between the different roles required for the proper construction of houses. Dependencies are inconvenient in a smoothly running construction process. Failures and remaining deficiencies are very often referred to lacking co-ordination between subsequent or parallel tasks of the process. The general problem is elaborated by for example Scherkenback (1991) when describing Deming's 14 quality assurance principles. For the construction process contributions by Sörensen (2003) and Appelqvist and Keijer (1994) could be referred to among many others. 


\section{THE OCCUPANCY PHASE}

\subsection{The away lock}

When the entrance door is locked with the away-lock, the water supply is automatically shut off two hours later, as well as gas or electricity to stove and sockets. Further, the ventilation in the bathroom is reduced (if the moisture detector does not indicate need for ventilation) and the burglar alarm is activated. When the resident returns the lamp in the hall is lit and the main water supply, the gas, the sockets and the ventilation are turned on automatically. The lamp in the hall is on until the resident switches it off manually.

\subsection{Typical events}

Significant events have been noticed during the early maintenance phase at Vallgossen. Two examples connected to the so called "away-lock"-function is described below.

Example 1: The automatic hall lamp broke in one flat. The cost to repair the lamp ended up at some 880 Euro, including error detection in software and replacement of vital hardware (which were not manufactured anymore). The resident was not willing to pay for the repair and it is still dark in the hall.

Example 2: Magnetic valves control the main water supply in the flats. The valves are connected to the away-lock. The residents have now, during the maintenance phase, discovered that many valves are out of order. In some flats all valves are broken. In some other flats only a single valve does not work. The crucial question that has arisen is when the valves stopped functioning - during the maintenance phase or as a result of a software error from the very beginning. No checking procedure is available via the smart home system if the valves are in order or not.

\subsection{Pulling out of responsibility}

The home network was developed during the IT boom in the end of the 1990s. The smart home system provider (the IT-company) held large visions about the future market of their system. Their visions have not come true. Today the maintenance of the home network has turned out to be a heavy burden to the company. The company now wants to replace the home 
network with an Internet-based system, albeit the warranty period is not yet terminated.

Table 3. Representation of status vector for a refrigerator (assumed example).

\begin{tabular}{|l|l|l|l|}
\hline Status vector & Description & Unit & Format \\
\hline $\begin{array}{l}\text { Temperature } \\
\text { (upper space) }\end{array}$ & Temperature in refrigerator upper space & ${ }^{\circ} \mathrm{C}$ & format_t \\
\hline $\begin{array}{l}\text { Temperature } \\
\text { (lower space) }\end{array}$ & Temperature in refrigerator lower space & ${ }^{\circ} \mathrm{C}$ & format_t \\
\hline Interior lamp & Function/no function & logical & format_x \\
\hline Interior lamp & Last exchange & date & format_d \\
\hline $\begin{array}{l}\text { Energy } \\
\text { consumption } \\
\text { record }\end{array}$ & Describes how information is represented & 'info' & format_f \\
\hline $\begin{array}{l}\text { Energy } \\
\text { consumption } \\
\text { vector }\end{array}$ & According to description & kWh & format_f.e \\
\hline Door open & Open/not open & logical & format_x \\
\hline $\begin{array}{l}\text { Door open } \\
\text { record }\end{array}$ & Describes how information is represented & 'info' & format_f \\
\hline $\begin{array}{l}\text { Door open } \\
\text { vector }\end{array}$ & According to description & 'time' & format_f.l \\
\hline
\end{tabular}

Obviously, the smart home market presently does not offer any viable long-term return opportunity. A sound attitude to the operation phase, with a time horizon of a decade, is required. Elaborate business models can hardly be applied to remedy this precarious situation without rethinking the basic technological requirements when applying ICT for the whole business. Smart homes should be regarded as a service to end users. A general aim for consumer products is to be able to apply the product effortlessly, without prior instruction or training ("plug-and-play"). The same principle must be the ultimate goal if effective business models would be able to establish long-term living in smart homes. Some initiatives are referred to Newmarch (2000), Coulouris et. al. (2001) and OSGi (2004).

Let us turn to another example in order to elaborate the issue a bit further.

4 Recording of energy consumption of the refrigerator could be summed up with the household's total energy consumption. It could serve as an alarm for a defect compressor performance.

${ }^{5}$ Could alert an alarm (on TV, on mobile phone, in home, in a relative's home)

${ }^{6}$ Could forward information on activity performed during a specific period (e.g. at supervision of old people) 


\section{EXCHANGE OF REFRIGERATORS SEEN AS A SMART HOME PROCEDURE}

\subsection{Status and control information}

Any equipment or function in a smart home is defined by a vector showing its status (Table 3), currently or over time, and another vector (Table 4) defining the control spectrum of the item.

Table 4. Representation of control vector for a refrigerator (assumed example).

\begin{tabular}{|l|l|l|l|}
\hline Control vector & Description & Unit & Format \\
\hline $\begin{array}{l}\text { Set temperature } \\
\text { (upper space) }\end{array}$ & $\begin{array}{l}\text { To specify temp. in refrig. upper } \\
\text { space }\end{array}$ & ${ }^{\circ} \mathrm{C}$ & format_t \\
\hline $\begin{array}{l}\text { Set temperature } \\
\text { (lower space) }\end{array}$ & $\begin{array}{l}\text { To specify temp. in refrig. lower } \\
\text { space }\end{array}$ & ${ }^{\circ} \mathrm{C}$ & format_t \\
\hline
\end{tabular}

\subsection{Replacing the refrigerator}

The old refrigerator is supposed to be integrated into the home network system offering the functions according to table 2 and 3 . The new one has to have similar properties if the home network system will offer the resident the same benefit and if no unwanted effects are to occur. The crucial parts are the physical connections and the understanding and interpretation of data that are to be exchanged with the new unit.

If we disregard the physical connection (let's assume RS232), the data representations are supposed not to be identical between the two systems (refrigerators). In principle, any of two situations may prevail, either the appliance manufacturers adapt to existing home network systems or the home systems on the market can handle all occurring refrigerators.?

\section{DISCUSSION}

Large demands are put particularly on two specific roles in figure 5, i.e. the project management and the smart home consultant. In the Vallgossen undertaking the subcontractor of the smart home system showed to be no

7 C.f. the way MS-Windows technically handles peripherals to be connected to PCs. Unfortunately, the situation on the home system market cannot be compared with the computer market. 
guarantee for the long-term maintenance. So, the question remains: "Do we have any candidate who can find a viable business opportunity by taking this long-term responsibility of smart home systems?" Hardly, anyone is to be found in the traditional construction process. A look at different service providers may reveal some opening. Tentatively, three marked actors are identified, which may be in the position, having interest in the existence of viable smart homes systems and, however less certain, having the necessary competence for maintaining long-term activity in the field. For the time being most in focus are 1) security systems providers, 2) providers of comfort and energy, and 3) caring providers.

Security companies could take this role since they already provide access systems to buildings. A security system could form a platform which would be able to integrate other subsystems and appliances.

Providers of climate comfort and energy systems already serve many commercial buildings with different systems of measurements and controls, which would be possible to adapt to single family houses and to individual flats in multi-family buildings. These systems could very well be extended to other smart homes functions, and form a basis for truly integrated systems.

Some large companies provide home care associated with technical support systems, which probably will become more common in the future.

These three categories of companies all have an interest in offering added value to the home. Generally, they also have a functioning administration and - apart from the home care providers - a technical tradition. These companies may have an interest in providing more integrated home systems, and they could fulfil the role as smart homes service provider.

\subsection{Requirements on the smart homes service provider}

The service provider needs a technical infrastructure with IT-systems that automatically connects all smart home systems at a distance. Necessary staff is required that can manage electrical installations, electronics and informatics for basic configurations (reconfigurations) on the site.

Activities during the running phase that the service provider should be able to perform are:

- Remotely check the status of the system.

- Become informed automatically of any dysfunction or defect of the system.

- Maintain and upgrade the system on site on a regular basis.

- Be able to assist on the site with minimal delay.

- Give around-the-clock support on-line and by telephone.

Still, the schema lacks one actor: the local technical service provider. The service provider monitors households in a large geographical area and 
cannot have service technicians available 24 hours a day seven day a week. Here the local technical service provider has a role to fulfil. If something in a home system fails, the resident should obtain support immediately. But the local technical service provider will be placed in a difficult position. He will probably not be able to influence the home system in its design and construction phase. He will be contracted by the end user and must deal with the home system regardless of its design and functions. One possibility is that the subcontractor of the smart home system has service agreements with a number of local technical service providers. In this situation the local technical service provider will have access to expertise knowledge about the smart home system. Another possibility is that all subcontractors' of smart home systems regularly educate local technical service providers about their specific home system. Figure 5 indicates the local technical service provider position between demanding customers/residents and a complex technical system (the smart homes system).

Another important issue to be aware of is the interconnection between the smart home system and Internet. If the end user contracts a service provider for maintenance of the home system, it will probably be monitored from a distance. This situation will put special demands on the home systems security. It is desirable to separate the smart homes system from the Internet. Otherwise, firewalls and virus programs must be included in the system. This situation will put a large responsibility on the resident, e.g. virus programs must be regularly updated. And still, it cannot be guaranteed as a $100 \%$ secure system. A smart home connected to Internet will always be exposed to external threats like hackers and viruses. On the other hand, if the home is separated from the Internet large demands will be put on equipment providers and smart homes systems to agree on far-reaching compatibility of components and parameters. 


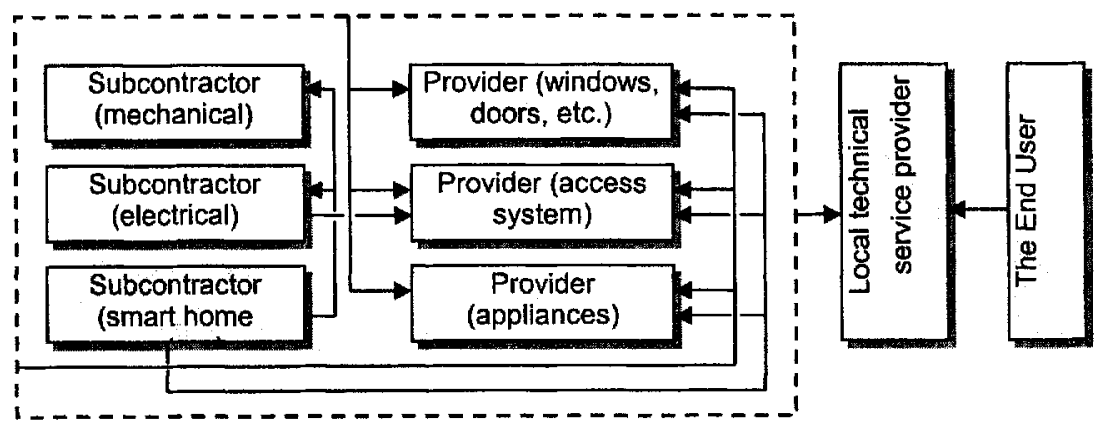

Figure 6. The local technical service providers place in a semantic schema.

\section{ACKNOWLEDGEMENT}

This work is funded by the Swedish Research Council Formas and the Development Fund of the Swedish Construction Industry (SBUF) which is duly acknowledged.

\section{REFERENCES}

Appelqvist I. and Keijer U. (1994). Building Integrity. Interaction between Building Parts, Systems and the Actors of the Building Process. CIB W78 Workshop on Computer Integrated Construction, August 22-24, 1994, Espoo, Finland.

Bamley J. B. and Ouchi W.G. (eds.) (1988). Organisational Economic, $2^{\text {nd }}$ ed. Jossey Bass Publishers, San Franscisco, Cal.

Coulouris, G., Dollimore, J. \& Kindberg, T. (2001). Distributed Systems - Concepts and Design, $3^{\text {rd }}$ Ed. Addison-Wesley, UK.

Eisenhardt, Kathleen, M. (1989) Agency Theory: An assessment and review. Academy of Management Review. Vol. 14:57-74

Jensen, M. C. and Meckling, W. H., (1976). "Theory of the Firm: Managerial Behavior, Agency Costs and Ownership Structure." Journal of Financial Economics, 3: 305-360

Junestrand, S. (2004). Being private and public at home - an architectural perspective on smart homes. TRITA-ARK Avh. 2004:3. School of Architecture, Royal School of Technology, Stockholm, Sweden.

Mayer, R.J. (ed) (1994). IDEF0 Function Modelling. A reconstruction of the original Air Force Wright Aeronautical Laboratory Technical Report AFWAL-TR-81-4023, Knowledge Based Systems, US.

Newmarch, J. (2000). A Programmer's Guide to JINI Technology. Apress, California.

OSGi Alliance. (2004). About the OSGi Service Platform. http:/www.osgi.org/

Sandström, G. and Keijer, U. (2003). Alloggi domotici integrati e di addestramento per persone con problemi mentali (Integrated smart living - Training flats for persons with 
acquired brain dysfunction). Abitare e Anziani Informa (Housing and Elderly Info), No. 12, pp 85-90.

Sandström, G., Werner, IB. and Keijer, U. (2003). Smart Homes Evaluated. Open House International, Vol. 28, No. 4.

Scherkenback, W. W. (1991). The Deming Route to Quality and Productivity. Road Maps and Roadblocks.

Sörensen, N. (2003). Co-ordination of the Design and Building Process for Optimal Building Performance. In Construction Process Improvement. Editor Atkin, B., Borgbrant, J. \& Josephson, P-E. Blackwell Publishing, UK.

Tarandi, V. (1998). Neutral Intelligent CAD Communication - Information exchange in construction based upon a minimal schema. Construction Management and Economics, Royal School of Technology, Stockholm, Sweden. 